\title{
The Relationship between Microbial Characteristics and Glomalin Concentrations of Controlled Horticultural Soils in Gyeongnam Province
}

\author{
Min Keun Kim, Yong Sik Ok ${ }^{1}$, Jae-Young Heo, Si-Lim Choi, Sang-Dae Lee, Hyun-Yul Shin, \\ Je-Hong Kim, Hye Ran $\mathrm{Kim}^{2} * *$, and Young Han Lee* \\ Gyeongsangnam-do Agricultural Research and Extension Services, Jinju 660-370, Republic of Korea \\ ${ }^{1}$ Biochar Research Center, Department of Biological Environment, Kangwon National University, \\ Chuncheon 200-701, Republic of Korea \\ ${ }^{2}$ Korea Research Institute of Bioscience and Biotechnology, Daejeon 305-806, Republic of Korea
}

(Received: March 20 2014, Accepted: April 11 2014)

Glomalin has been suggested as an enhancer for soil stability by promoting the aggregation. In this study, we examined the concentrations of glomalin and microbial characteristics in 25 controlled horticultural soils sampled from Gyeongnam Province. Total glomalin had a significant positive correlation with soil organic matter $(p<0.01)$, soil microbial biomass carbon $(p<0.05)$, and dehydrogenase activity $(p<0.05)$ in controlled horticultural soils. In addition, the total glomalin had a significant positive correlation with concentrations of total fatty acid methyl esters, Gram-negative and Gram-positive bacteria, fungi, and arbuscular myconhizal fungi in controlled horticultural soils $(\boldsymbol{p}<\mathbf{0 . 0 0 1})$. In conclusion, the concentration of total glomalin could be an indicator of microbial biomass richness for sustainable agriculture in controlled horticultural soils.

Key words: Glomalin, Soil microbial biomass C, Dehydrogenase, Controlled horticulture
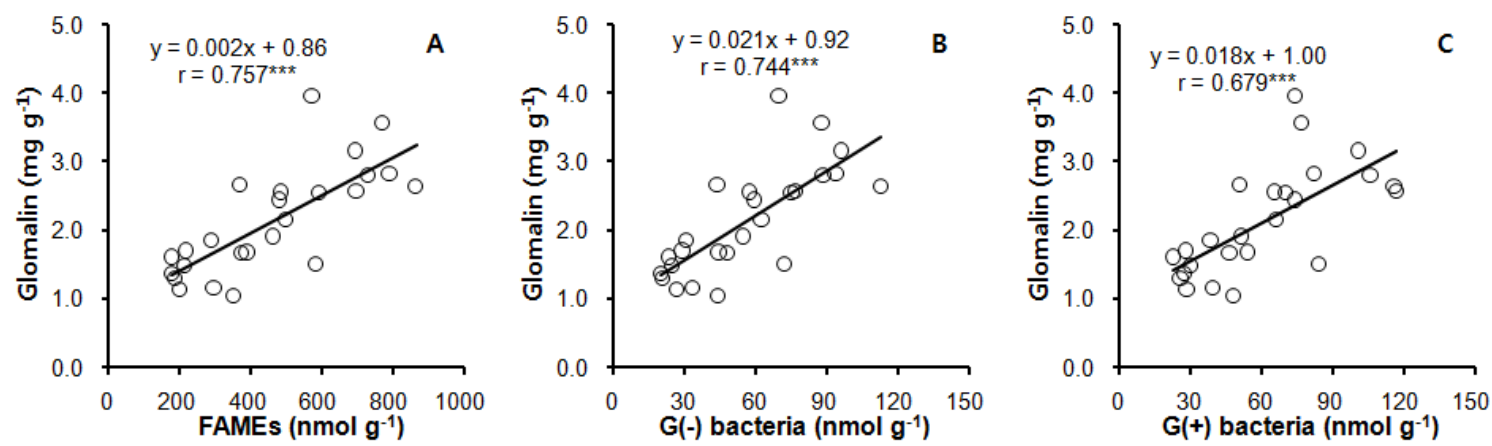

Relationship between glomalin and fatty acid methyl esters (FAMEs, A), Gram-negative bacteria (B), and Gram-positive bacteria $(C)$ in controlled horticultural soils.

\footnotetext{
*Corresponding author : Phone: +82552541313, E-mail: lyh2011@korea.kr

**Co-Corresponding author : Phone: +821020777133, E-mail: kimhr@kribb.re.kr

$\dagger$ The first two authors equally contributed to this work.

§Acknowledgement: This study was conducted with the support of the Research Cooperating Program for Agricultural Science \& Technology Development (Project No. PJ009198252014), RDA, Republic of Korea.
} 


\section{Introduction}

작물의 양분관리를 위해서는 토양분석에 따른 맞춤형 시 비처방이 필요하지만 시설재배지는 비료의 과다시비로 염 류집적과 양분 불균형이 심각한 실정이다 (Choi et al., 2010, Lee et al., 2013). 이러한 토양에 살고 있는 미생물은 스트 레스를 받으므로 친환경농업을 추진하기 위해서는 미생물 의 활성을 높이는 것이 매우 중요하다 (Lee and Kim, 2011; Lee and Yun, 2011). 토양의 미생물 활성을 나타내는 지표 는 미생물 생체량, 탈수소 효소 등이 있으며 최근에는 내생균 근균이 분비하는 당단백질인 글로말린 함량이 있다 (Gillespie et al., 2011; Rilling et al., 2005; Wright and Upadhyaya, 1996). 일반적으로 글로말린 관련 토양 단백질은 토양 유기 물 함량의 5.4-21.2\%를 차지하고 있으며 (Vodnik et al., 2008) 경운을 하게 되면 내생균근균의 개체수가 감소되어 글로말 린 함량이 낮아지는 것으로 알려져 있다 (Alguacil et al., 2008; Wright et al., 1999). 국내에서는 보리나 호밀을 처 리한 토양 보다 헤어리베치를 처리한 토양에서 글로말린 함 량이 높았고 (Jeon et al., 2010) 유기재배 토양이 관행재배 토양 보다 1.2배 높은 것으로 보고되었다 (Min et al., 2011). 글로말린은 토양을 입단화 하는 물질로서 물에 용해되지 않 고 내생균근균의 균사가 소멸되어도 토양에 오랫동안 존재 하여 탄소와 질소를 저장하여 온실가스를 감축하는 역할을 한다 (Driver et al., 2005; Rilling, 2004; Wilson et al., 2009; Wright and Anderson, 2000). 그러나 이러한 유익한 작용에도 불구하고 아직까지 우리나라 일반농경지에서 글 로말린에 대한 연구는 미흡한 실정이며 기후변화 대응 및 친환경농업을 육성하기 위해서는 기초적인 연구결과가 요 구된다.

따라서 본 연구는 경남지역 시설재배지의 토양 미생물 특성과 글로말린 함량을 조사하고 글로말린 함량에 미치는 여러 가지 요인을 검토하였다.

\section{Materials and Methods}

시료채취 및 화학성 분석 경남지역 시설재배지 토양 의 미생물 특성과 글로말린 함량을 분석하기 위하여 2012년 에 고추 4 , 딸기 8 , 수박 5 , 토마토 4 , 호박 4 개소 등 25 개소를 선정한 후 4월에서 5 월 사이에 표토를 0-15 cm 깊이에서 500 $\mathrm{g}$ 정도를 3 반복으로 채취하였다. 채취한 토양은 실험실에서 풍건하여 $2 \mathrm{~mm}$ 체를 통과된 것을 농촌진흥청 농업과학기술 원 토양화학분석법 (NIAST, 2010)을 적용하여 Tyurin법으로 유기물을 분석하였다.

미생물 활성 및 글로말린 분석방법 글로말린 함량, 미생물체량 및 탈수소효소 활성과 미생물 군집 분석을 위해
채취한 토양은 $-20^{\circ} \mathrm{C}$ 에 2 일간 보관한 후 동결건조하고 2 $\mathrm{mm}$ 체를 통과시킨 토양을 분석에 사용하였다. 글로말린 함 량은 Wright et al. (2006)이 제시한 $100 \mathrm{mM}$ (pH 9.0) sodium pyrophosphate 추출법을 사용하였다. 토양 $2.0 \mathrm{~g}$ 에 $100 \mathrm{mM}$ sodium pyrophosphate (pH 9.0) $8 \mathrm{~mL}$ 를 첨가하여 $121^{\circ} \mathrm{C}$ 에 서 1 시간 가압으로 추출한 후 $5,000 \times \mathrm{g}$ 에서 10 분간 원심분 리하여 상등액을 채취하고 Bradford dye-binding assay법을 적용하여 비색계 (UV-1650PC, Shimadzu Co., Kyoto, Japan) 로 분석하였다. 미생물체량은 Vance et al. (1987)이 제안한 chloroform fumigation-extraction법을 사용하였고 탈수소 효소 활성은 2,3,5-triphenyltetrazolium chloride (TTC) 분 석법을 적용하였다 (Casida et al., 1964).

미생물 함량 분석 미생물 함량은 세포막 지방산을 fatty acid methyl ester (FAME)로 변형하여 분석하는 방법으로 GC Agilent 6890N (Agilent Technologies, USA)과 HP-ULTRA 2 capillary column $(25 \mathrm{~m} \times 0.2 \mathrm{~mm} \times 0.33 \mu \mathrm{m}$ film thickness, Agilent Technologies, USA)을 이용하여 분석하였다 (Schutter and Dick, 2000). 분석결과는 MIDI software program package (MDI, Inc., Newark, DE)을 이용하여 각각의 지방산에 대 한 미생물 군집을 분석하였다 (Hamel et al., 2006). 그람음 성 세균은 $16: 1 \omega 7 \mathrm{c}, 18: 1 \omega 7 \mathrm{c}, \mathrm{cy} 17: 0$ 및 cy19:0, 그람양성 세 균은 i15:0, a15:0, i16:0, i17:0 및 a17:0을 합산하였다 (Zelles,

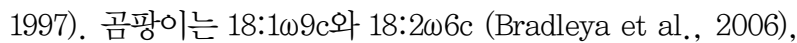
arbuscular mycorrhizal fungi는 16:1 $1 \omega 5 \mathrm{c}$ 를 적용하였다 (Balser et al., 2005; Frosteg rd et al., 1993; Olsson et al., 1998).

상관관계 분석 분석된 결과 값은 SAS 프로그램 9.1.3 버젼 (2006)을 사용하여 분석된 결과 값과 글로말린 함량의 상관관계를 검토하였다.

\section{Results and Discussion}

유기물과 미생물 활성, 글로말린 상관관계 시설재배 지 토양의 유기물 함량은 Fig. 1과 같이 미생물체량 ( $\mathrm{r}=0.645$, $p<0.001)$, 탈수소 효소 활성 $(\mathrm{r}=0.513, p<0.01)$, 글로말 린 함량 $(\mathrm{r}=0.525, p<0.01)$ 과 정의 상관관계를 나타냈다. 시설재배지의 미생물체량은 $105-839 \mathrm{mg} \mathrm{kg}^{-1}$ 으로 평균 371 $\mathrm{mg} \mathrm{kg}^{-1}$ 을 나타냈다 (Fig. 1A). 시설재배지의 미생물체량은 Lee and $\mathrm{Ha}$ (2011)가 보고한 밭토양 평균인 $268 \mathrm{mg} \mathrm{kg}^{-1}$ 보 다 1.4배 많은 것으로 나타났다. 탈수소 효소 활성은 44-320 $\mu \mathrm{g} \mathrm{TPF} \mathrm{g}{ }^{-1} 24 \mathrm{~h}^{-1}$ 으로 평균 $84 \mu \mathrm{g} \mathrm{TPF} \mathrm{g}{ }^{-1} 24 \mathrm{~h}^{-1}$ 이었으며 (Fig. 1B) 밭토양 평균 $71 \mu \mathrm{g} \mathrm{TPF} \mathrm{g}{ }^{-1} 24 \mathrm{~h}^{-1}$ 보다 1.2배 많았 다 (Lee and Ha, 2011).

그리고 글로말린 함량은 $1.04-3.96 \mathrm{mg} \mathrm{g}^{-1}$ 으로 평균 1.80 $\mathrm{mg} \mathrm{g}^{-1}$ 으로 나타났으며 (Fig. 1C) Min et al. (2011)이 보고 

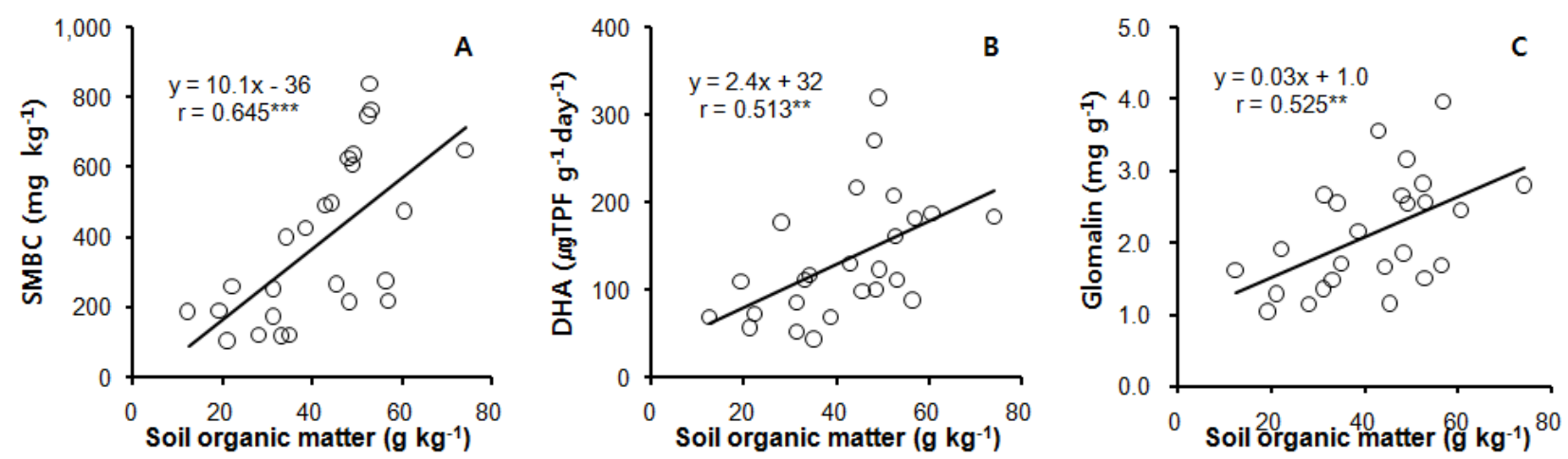

Fig. 1. Relationship between soil organic matter and soil microbial biomass Carbon (SMBC, A), dehydrogenase activity (DHA, B), and glomalin $(\mathrm{C})$ in controlled horticultural soils.
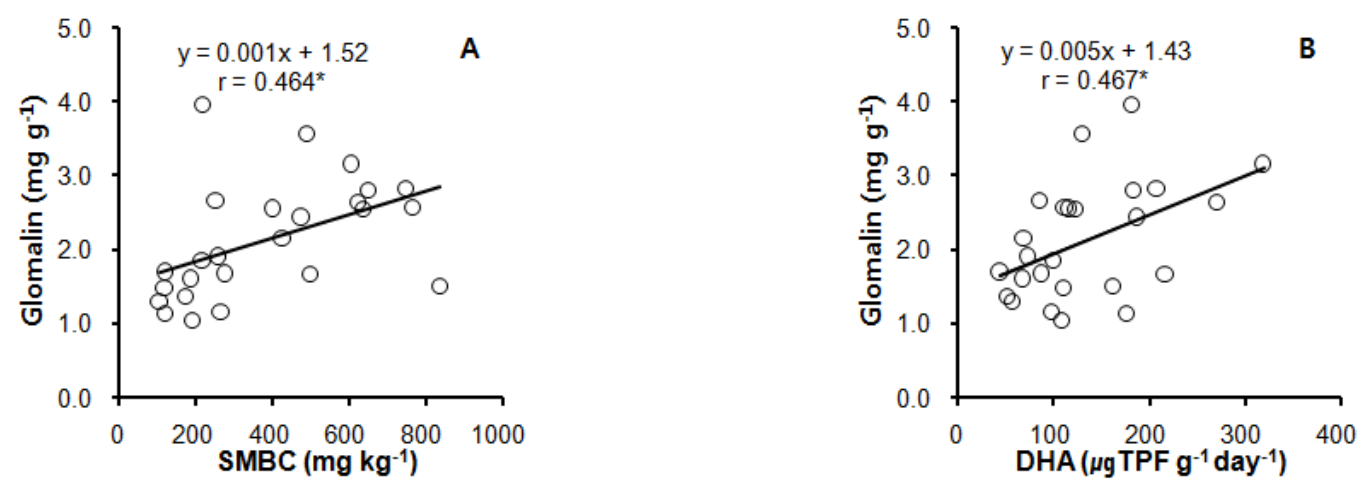

Fig. 2. Relationship between glomalin and soil microbial biomass Carbon (SMBC, A) and dehydrogenase activity (DHA, B) in controlled horticultural soils.

한 시설재배지 유기농 토양 $2.00 \mathrm{mg} \mathrm{g}^{-1}$, 무농약 토양 1.93 $\mathrm{mg} \mathrm{g}^{-1}$ 보다 낮았으나 관행농 토양 $1.68 \mathrm{mg} \mathrm{g}^{-1}$ 보다 높았 다. 시설재배지 토양의 유기물 함량과 글로말린 함량과의 관계는 Lee et al. (2012)이 보고한 논토양의 결과와 일치하 였다. 이러한 결과는 글로말린 자체가 당단백질이기 때문에 토양 유기물 함량과 밀접한 관계를 보인 것으로 생각 된다 (Min et al., 2011; Vodnik et al., 2008; Wrigh et al., 1996; Wrigh et al., 2007). He et al. (2010)은 사질토양에서도 유 기물 함량과 글로말린 함량이 정의상관 관계를 나타낸다고 하였고 Wright et al. (2007)은 경운 방법에 따라 글로말린 함량이 토양 유기물 함량의 6-9\%를 차지하고 있다고 하였 다. 그러나 본 연구에서 글로말린 함량은 토양 유기물 함량의 2.5-12.9\%로서 평균 3.9\%를 나타냈으며 Lee et al. (2012) 이 보고한 논토양 평균인 $2.8 \%$ 보다 1.4 배 높은 것으로 나 타났다.

미생물 활성과 글로말린 상관관계 시설재배지 토양 의 미생물체량은 Fig. $2 \mathrm{~A}$ 와 같이 토양 글로말린 함량과 정 의상관을 나타냈다 $(\mathrm{r}=0.464, p<0.05)$. 이러한 결과는 미 생물체량이 많을수록 글로말린 함량이 높다고 보고한 결과 와 일치하였다 (Lee and Kim, 2011; Lee and Yun, 2011;
Lee et al., 2012; Zhang et al., 2012). 시설재배지에서 탈 수소 반응을 촉매하는 산화환원 효소로서 호흡 및 발효 등 의 대사과정에 매우 중요한 탈수소효소 활성과 글로말린 함 량의 관계는 논토양과 유사한 정의상관 (Fig. $2 \mathrm{~B}, \mathrm{r}=0.467$, $p<0.05$ )을 보였다 (Lee et al., 2012).

미생물 함량과 글로말린 상관관계 토양 미생물의 총 FAME 함량은 178-866 nmol g ${ }^{-1}$ 으로 평균 $385 \mathrm{nmol} \mathrm{g}^{-1}$ 이었으 며 글로말린 함량과 정의상관을 나타냈다 (Fig. 3A, r=0.757, $p<0.001)$. 그람음성 세균 함량은 $20-113 \mathrm{nmol} \mathrm{g}^{-1}$ 으로 평 균 $48 \mathrm{nmol} \mathrm{g}^{-1}$ 이었으며 글로말린 함량과 정의상관을 보였 다 (Fig. 3B, $\mathrm{r}=0.744, p<0.001$ ). 그람음성 세균은 토양 비 옥도가 낮은 경우 민감하게 개체수가 감소한다 (Kieft et al., 1997). 따라서 토양 양분의 개선으로 일반적인 세균의 활성 이 증가하면 글로말린 함량도 높아지는 것으로 생각되었다 (Lee and Yun, 2011; Lee et al., 2012). 그람양성 세균 함량 은 23-117 nmol g${ }^{-1}$ 으로 평균 $46 \mathrm{nmol} \mathrm{g}{ }^{-1}$ 이었으며 글로말 린 함량과 정의 상관관계를 보였다 (Fig. $3 \mathrm{C}, \mathrm{r}=0.679, p<$ 0.001). 일반적으로 그람음성 세균은 유기물을 이용할 때 그람양성 세균 보다 활동성이 크고 빨리 생육하는 것으로 알려져 있으며 (Mechri et al., 2010) 본 연구에서는 Lee and 

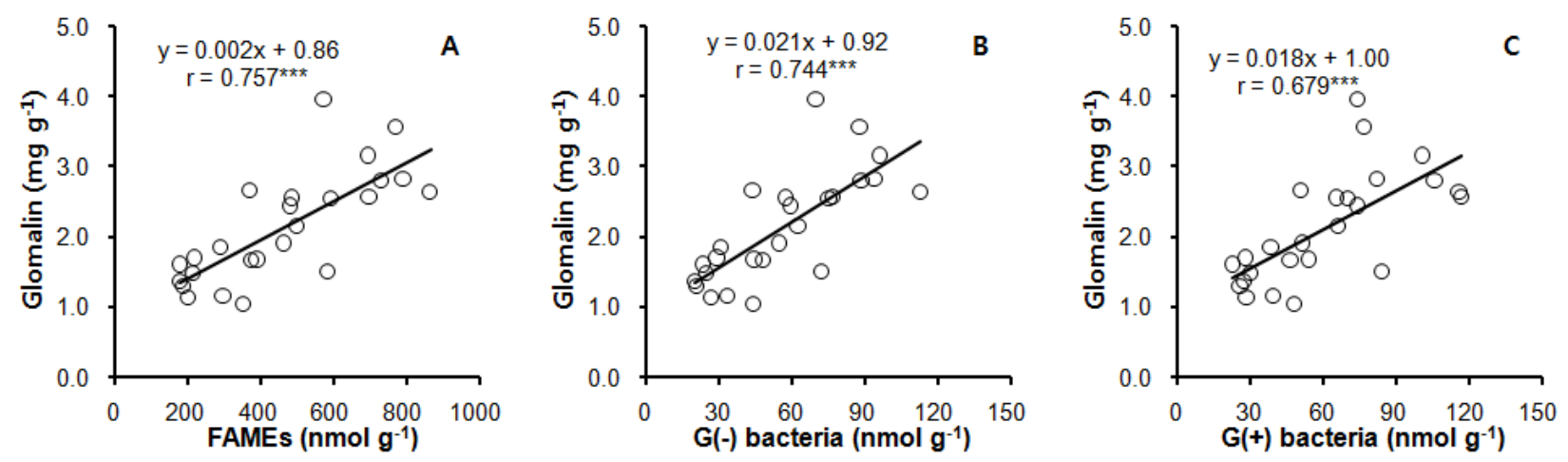

Fig. 3. Relationship between glomalin and fatty acid methyl esters (FAMEs, A), Gram-negative bacteria (B), and Gram-positive bacteria $(C)$ in controlled horticultural soils.
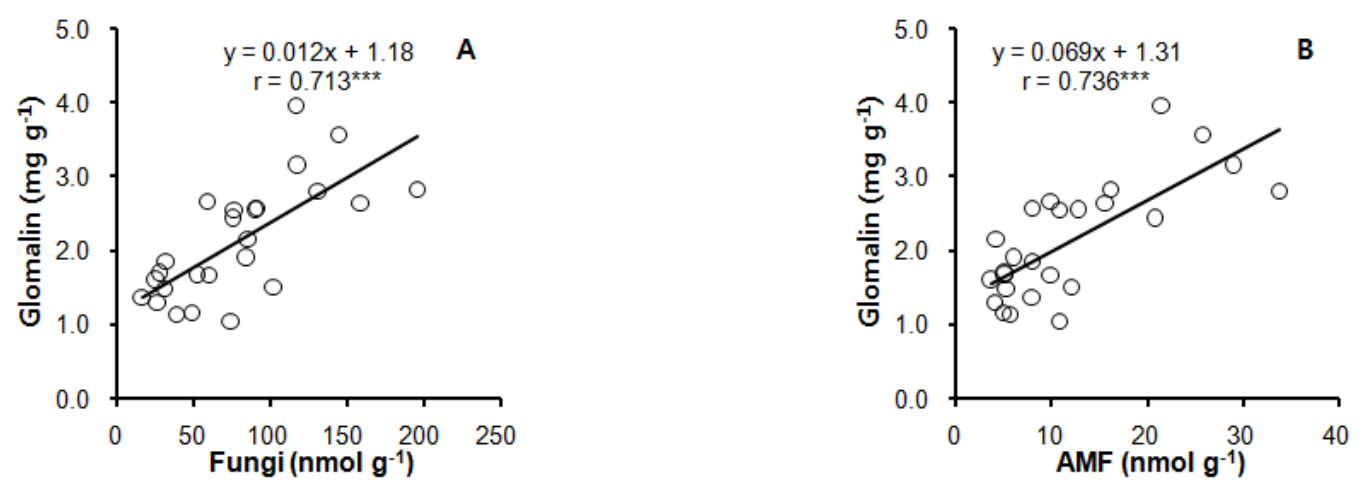

Fig. 4. Relationship between glomalin and fungi (A) and arbuscular myconhizal fungi (B) in controlled horticultural soils.

$\operatorname{Kim}$ (2011)이 보고한 밭토양 보다 그람음성 세균 함량이 높 은 것으로 나타났다.

토양 곰팡이 함량은 $178-866 \mathrm{nmol} \mathrm{g}^{-1}$ 으로 평균 $385 \mathrm{nmol}$ $\mathrm{g}^{-1}$ 이었으며 (Fig. $4 \mathrm{~A}, \mathrm{r}=0.713, p<0.001$ )과 내생균근균 (Fig. 4B, $\mathrm{r}=0.736, p<0.001$ ) 함량도 글로말린 함량과 정 의 상관관계을 나타냈다. 이러한 결과는 Lee and $\operatorname{Kim}(2011)$ 이 밭토양에서 글로말린 함량은 내생균근균과 유의적인 상 관관계가 있다고 보고한 결과와 일치하였다. 일반적으로 토 양에서 글로말린은 400 일 이후에도 $50 \%$ 가 검출될 정도로 매우 안정한 형태로 알려져 있으며 (Rillig et al., 2003) 분 석방법도 미생물체량이나 탈수소 효소 활성 분석 보다 시간 이 단축되는 장점이 있다. 따라서 일반농경지에서 미생물 활성 및 함량과 유의적인 상관관계를 나타내는 글로말린의 함량을 지속적으로 조사하여 농업생태계의 지표로서 활용 할 수 있을 것으로 기대된다.

\section{Conclusions}

경남지역 시설재배지의 미생물 특성과 글로말린 함량의 관계를 분석하기 위하여 2012년에 25개소를 선정하여 분석 하였다. 토양 유기물 함량에 따른 미생물체량, 탈수소효소 활성 및 글로말린 함량은 정의 상관관계를 나타냈다. 그리고
미생물체량, 탈수소 효소 활성, 그람음성 및 그람양성 세균, 곰팡이, 내생균근균 함량도 글로말린과 정의 상관관계를 보 였다. 따라서 당단백질인 글로말린은 기후변화 대응 및 친환 경농업과 관련하여 토양 지표로서 활용할 수 있을 것으로 판 단되며 현장적용을 위해서는 토양 내 함량 수준을 지속적으 로 검토해야 할 필요가 있다.

\section{References}

Alguacil, M.M., E. Lumini, A. Roldá, J.R. Salinas-Garcí, P. Bonfante, and V. Bianciotto. 2008. The impact of tillage practices on arbuscular mycorrhizal fungal diversity in subtropical crops. Ecol. Appl. 18:527-536.

Balser, T., K.K. Treseder, and M. Ekenler. 2005. Using lipid analysis and hyphal length to quantify AM and saprotrophic fungal abundance along a soil chronosequence. Soil Biol. Biochem. 37:601-604.

Bradleya, K., A. Rhae, R.A. Drijberb, and J. Knopsc. 2006. Increased $\mathrm{N}$ availability in grassland soils modifies their microbial communities and decreases the abundance of arbuscular mycorrhizal fungi. Soil Biol. Biochem. 38:1583-1595.

Casida, L.E., D.A. Klein, and T. Santoro. 1964. Soil dehydrogenase activity. Soil Sci. Soc. Am. J. 47:599-603.

Choi, M.T., J.I. Lee, Y.U. Yun, J.E. Lee, B.C. Lee, E.S. Yang, 
and Y.H. Lee. 2010. Relationship between fertilizer application level and soil chemical properties for strawberry cultivation under greenhouse in Chungnam Province. Korean J. Soil Sci. Fert. 43(2):153-159.

Driver, J.D., W.E. Holben, and M.C. Rillig. 2005. Characterization of glomalin as a hyphal wall component of arbuscular mycorrhizal fungi. Soil Biol. Biochem. 37(1):101-106.

Frostegård, Å., A. Tunlid, and E. Bååth. 1993. Phospholipid fatty acid composition, biomass and activity of microbial communities from two soil types experimentally exposed to different heavy metals. Appl. Environ. Microbiol. 59:3605-3617.

Gillespie, A.W., R.E. Farrell, F.L. Walley, A.R.S. Ross, P. Leinweber, K. Eckhardt, T.Z. Regier, and R.I.R. Blyth. 2011. Glomalin-related soil protein contains non-mycorrhizal-related heat-stable proteins, lipids and humic materials. Soil Biol. Biochem. 43:766-777.

Hamel, C., K. Hanson, F. Selles, A.F. Cruz, R. Lemke, B. McConkey, and R. Zentner. 2006. Seasonal and long-term resource-related variations in soil microbial communities in wheat-based rotations of the Canadian prairie. Soil Biol. Biochem. 38:2104-2116.

He, X., Y. Li, and L. Zhao. 2010. Dynamics of arbuscular mycorrhizal fungi and glomalin in the rhizosphere of Artemisia ordosica Krasch. in Mu Us sandland, China. Soil Biol. Biochem. 42:1313-1319.

Jeon, W.T., K.Y. Seong, M.T. Kim, G.J. Oh, I.S. Oh, and U.G. Kang. 2010. Changes of soil physical properties by glomalin concentration and rice yield using different green manure crops in paddy. Korean J. Soil Sci. Fert. 43:119-123.

Kieft, T.L., E. Wilch, K. O'connor, D.B. Ringelberg, and D.C. White. 1997. Survival and phospholipid fatty acid profiles of surface and subsurface bacteria in natural sediment microcosms. Appl. Environ. Microbiol. 63:1531-1542.

Lee, Y.H. and H.D. Yun. 2011. Changes in microbial community of agricultural soils subjected to organic farming system in Korean paddy fields with no-till management. J. Korean Soc. Appl. Biol. Chem. 54(3):434-441.

Lee, Y.H. and H. Kim. 2011. Response of soil microbial communities to different farming systems for upland soybean cultivation. J. Korean Soc. Appl. Biol. Chem. 54(3):423-433.

Lee, Y.H. and S.K. Ha. 2011. Impacts of chemical properties on microbial population from upland soils in Gyeongnam Province. Korean J. Soil Sci. Fert. 44:242-247.

Lee, Y.H., M.K. Kim, and Y.S. Ok. 2012. The relationship between microbial characteristics and glomalin concentrations in paddy soils of Gyeongnam Province. Korean J. Soil Sci. Fert. 45(5):792-797.

Lee, Y.H., S.T. Lee, M.A. K.P. Hong, S.D. Lee, J.H. Kim, Y.S. Ok, M.K. Kim, and H.R. Kim. 2013. Long-term variations of chemical properties in controlled horticultural soils of Gyeongnam Province. Korean J. Soil Sci. Fert. 46(5):308-312.

Mechri, B., H. Chehab, F. Attia, F.B. Mariem, M. Braham, and
M. Hammami. 2010. Olive mill wastewater effects on the microbial communities as studied in the field of olive trees by analysis of fatty acid signatures. Eur. J. Soil Bio. 146:312-318. Min, S.G., S.H. Lee, S.H. Nam, Y.U. Choi, S.Y. Lee, S.S. Park, S.T. Lee, E.S. Kim, W.D. Song, and Y.H. Lee. 2011. Effect of different cultivation systems on soil glomalin content and nutrient uptake of strawberry in controlled horticultural land. Korean J. Soil Sci. Fert. 44:452-456.

NIAST. 2010. Methods of analysis of soil and plant. National Institute of Agricultural Science and Technology, Suwon, Korea (In Korean).

Olsson, P.A., R. Francis, D.J. Read, and B. Söderström. 1998. Growth of arbuscular mycorrhizal mycelium in calcareous dune sand and its interaction with other soil micro-organisms as estimated by measurement of specific fatty acids. Plant Soil 201:9-16.

Rillig, M.C. 2004. Arbuscular mycorrhizae, glomalin, and soil aggregation. Can. J. Soil Sci. 84:355-363.

Rilling, M.C., E.R. Lutgen, P.W. Ramsey, J.N. Klironomos, and J.E. Gannon. 2005. Microbiota accompanying different arbuscular mycorrhizal fungal isolates influence soil aggregation. Pedobiologis 49:251-259.

Rillig, M.C., P.W. Ramsey, S. Morris, and E.A. Paul. 2003. Glomalin, an arbuscular-mycorrhizal fungal soil protein, responds to land-use change. Plant Soil volume: 293-299.

SAS. 2006. SAS enterprise guide Version 4.1. SAS Inst., Cary, NC.

Schutter, M.E. and R.P. Dick. 2000. Comparison of fatty acid methyl ester (FAME) methods for characterizing microbial communities. Soil Sci. Soc. Am. J. 64:1659-1668.

Vance, E.D., P.C. Brookes, and D.S. Jenkinson. 1987. An extraction method for measuring soil microbial biomass carbon. Soil Biol. Biochem. 19:703-707.

Vodnik, D., H. Grcman, I. Macek, J.T. van Elteren, and M. Kovacevic. 2008. The contribution of glomalin-related soil protein to $\mathrm{Pb}$ and $\mathrm{Zn}$ sequestration in polluted soil. Sci. Total Environ. 392:130-136.

Wilson, G.W.T., C.W. Rice, M.C. Rillig, A. Springer, and D.C. Hartnett. 2009. Soil aggregation and carbon sequestration are tightly correlated with the abundance of arbuscular mycorrhizal fungi: results from long-term field experiments. Ecol. Lett. 12:452-I461.

Wright, S.F. and A. Upadhyaya. 1996. Extraction of an abundant and unusual protein from soil and comparison with hyphal protein from aruscular mycorrhizal fungi. Soil Sci. 161(9): 575-596.

Wright, S.F. and R.L. Anderson. 2000. Aggregate stability and glomalin in alternative crop rotations for the central Great Plains. Biol. Fertil. Soils 31:249-253.

Wright, S.F., J.L. Starr, and I.C. Paltineanu. 1999. Changes in aggregate stability and concentration of glomalin during tillage management transition. 63:1825-1829. 
Wright, S.F., K.A. Nichols, and W.F. Schmidt. 2006. Comparison of efficacy of three extractants to solubilize glomalin on hyphae and in soil. Chemosphere 64:1219-1224.

Wright, S.F., M. Franke-Snyder, J.B. Morton, and A. Upadhyaya. 1996. Time-course study and partial characterization of a protein on hyphae of arbuscular mycorrhizal fungi during active colonization of roots. Plant Soil 181:193-203.

Wright, S.F., V.S. Green, and M.A. Cavigelli. 2007. Glomalin in aggregate size classes from three different farming systems. Soil Till. Res. 94:546-549.

Zelles, L. 1997. Phospholipid fatty acid profiles in selected members of soil microbial communities. Chemosphere 35:275-294.

Zhang, S., Q. Li, X. Zhang, K. Wei, L. Chen, and W. Liang. 2012. Effects of conservation tillage on soil aggregation and aggregate binding agents in black soil of Northeast China. Soil Till. Res. 124:196-202. 